
Research Article

\title{
Factors influencing long term tomato seed production under contract farming
}

\author{
Chalee Gedgaew ${ }^{1,}$, Suchint Simaraks ${ }^{2}$, and A. Terry Rambo ${ }^{2}$ \\ 1 Program on Business Economics, Faculty of Management Science, Udon Thani Rajabhat University. \\ 41000, Thailand. Email: cgedgaew@gmail.com \\ 2 Program on System Approaches in Agriculture, Faculty of Agriculture, Khon Kaen University. 40002, \\ Thailand. \\ * Corresponding author
}

\begin{abstract}
Hybrid tomato seed production under contract farming in Northeast Thailand has been declining after three decades of initial introduction. However, some growers in some villages remain as long-term growers. This study was designed to identify factors influencing their long-term production decision making process. A purposive sampling technique was used to select the study sites and key informants for in-depth semi-structured interviews. Group interviews were conducted to validate the data. The contract hybrid tomato seed production system is a centralized model. It is based on a two-way contractual relationships between the company and the individual grower. The companies specify production systems and produce quality standards at a fixed time and price. They support a complete package of inputs credit, loans and extension services to the growers. Costs of all inputs and loans are deducted from the seed payment. These costs are usually forgiven when the crop fails through no fault of the growers. The growers cannot produce hybrid tomato seeds without a contract due to the proprietary germplasm. The quality of the product and marketing are also controlled by the companies. The companies must depend on the farmers' knowledge however, for the management and technical skills. Therefore, the companies must allow considerable flexibility and leniency in enforcing the terms of the contracts. As a result, knowledgeable and skillful growers are vital factors in sustaining long term hybrid tomato seed production. Furthermore, grower's personal characteristics stand out as an important factor for long term production. This is why the companies are lenient and flexible with the growers to sustain their mutual benefit.
\end{abstract}

Keywords: sustainable production; intensification; skilled labor; farmer decision making; contract farming; tomato

\section{Introduction}

Technological developments, demographic changes, consumer preference changes, trade liberalization and financial capital mobility have shifted agricultural production and trade to High Value Foods (HVFs) such as fruit and vegetables, poultry, seeds, dairy products and shellfish. Since the 1990s, HVFs were roughly twice the value of the traditional export crops such as coffee, tea, sugar, cotton, cocoa and tobacco. Production of these HVF crops is structured by contracts between agribusiness firms and smallholders in developing countries (Rosset et al., 1999; Da Silva, 2005; Winters et al., 2005).

Thailand is one of the pioneers in the development of contract farming in Asia. Initially beginning with sugarcane and tobacco, this system has expanded to vegetable crops, seeds and processed foods such as canned fish, pineapples and tomato products (Saenjan, 1998; Singh, 2005; Sriboonchitta and Wiboonpongse, 2008). However, the contract system has raised serious concerns regarding social justice, environmental sustainability and corporate control and has in many cases, become an elaborate way of exploiting small farmers (Siamwalla 1996; Delforge 2007).

In Northeast Thailand, tomato seed production under contract farming emerged more than three decades ago (Gedgaew et al., 2017). It has expanded into many villages in both rainfed and 
irrigated rice areas. Previous researchers generally believed that the provision of irrigation water was a vital factor for the success of vegetable seed production (Benziger, 1996; Rosset et al., 1999; Sriboonchitta and Wiboonpongse, 2008) but a recent survey conducted by the authors in 2013/14 found that seed production in irrigated land has decreased while it has been increasing in rainfed rice areas. However, even in rainfed rice areas, production is confined to only a few villages (Gedgaew et al., 2017). This finding has raised the question of why tomato seed production under contract farming has continued for a long period of time in certain villages in rainfed rice areas. Hence, this study was undertaken with the following specific objectives: 1) to describe the contract tomato seed production system in rainfed rice areas, and 2) to identify the factors influencing the continuation of the tomato seed production under contract farming in rainfed rice areas of Northeast Thailand.

\section{Materials and methods}

From October 2013 to March 2014, we conducted an exploratory field study on tomato seed production under contract farming in Northeast Thailand. We found that although this system had earlier expanded into many villages, both in rainfed and irrigated rice areas, over time production had become concentrated in a smaller number of villages especially in the rainfed rice areas. Hence, for this study we purposively selected a rainfed area in Khon Kaen province where many long term growers are concentrated.

Since the late 1970s, tomato seed production greatly expanded into many villages in Mueang district in Khon Kaen province. However, production is now concentrated in selected sites in Lat $\mathrm{Na}$ Phiang and Wang To villages. Therefore, these two villages were purposively selected as the site of the study.

Official statistics and documents that provide data on the study site were collected from provincial and district agriculture extension offices, as well as the sub-district municipalities and the sub-district hospitals. A preliminary household survey was conducted by interviewing 73 village health volunteers for identifying tomato seed contract growers. In-depth semi-structured interviews (SSI) with 15 villagers who had knowledge about the village context and history of tomato seed production were conducted. Data were collected at the household level by applying both in-depth interviews and non-participant observation covering 39 long term growers who had been producers for more than 10 years. The sub-topics consisted of household resources, cropping system, tomato seed production system, and factors influencing continuity and discontinuity of production. Data triangulation included in-depth interviews with 11 former growers who had ceased production and 8 seed company staff who had been operating at the production sites. Furthermore, group interviews of long-term growers and former growers were also conducted.

\section{Results and discussion}

\subsection{Historical development of tomato seed production in the study site}

At Lat Na Phiang and Wang To villages, the production of tomato seed began in 1983 and 1984, respectively (Kerdsuk et al., 1996). The production season started after the rainy season and rice was harvested. Beginning in November, the company provided a foundation of seeds to the growers who raised the seedlings in nursery plots in their paddy fields. Tomato seedlings were then transplanted into the production plots in December and the ripe fruit was harvested in March. Each of the growers had grown only one plot (about $400 \mathrm{~m} 2$ ) with 1,200 tomato plants. The company provided inputs on credit, direct loans for hiring laborers, extension services, and purchased quality tomato seeds at an agreed price. The credits and loans were deducted from the post-harvest payment. Seed company staff was also involved in training the growers by demonstrations and hands-on practice along with monitoring visits (Kerdsuk et al., 1996; Martwanna and Lertrat, 2007). 
In the crop year of 1991/92, there were 230 and 107 contract growers or $76.9 \%$ and $17.2 \%$ of total households at Lat $\mathrm{Na}$ Phiang and Wang To village, respectively (Kerdsuk et al. 1996).

In the crop year of 1994/95, most growers started to grow two plots in a single season with the first plot from October to January (after harvesting short-duration rice) and the second plot from November to February (after harvesting long-duration rice). The size of the plots was about 400 $600 \mathrm{~m} 2$ with 1,000-1,500 tomato plants. In the crop year of 1998/99, some growers began to grow three plots in a single season; the first plot was from October to January, the second plot was from November to February, and the third plot was from late November to March (Martwanna and Lertrat, 2007).

In the crop year of 2014/15, village health volunteers indicated that there were 197 and 36 contract growers or $53.5 \%$ and $7.0 \%$ of total households in Lat Na Phiang and Wang To village, respectively. Most growers had 2 - 4 plots, each plot with a different variety, with a total area of about $1600 \mathrm{~m} 2$ and had production contracts with 1 to 3 companies each production season. More than ten seed companies, both International and Thai, have operated at this production site. According to seed company staff their contract growers were mainly concentrated at Lat Na Phiang village while the number of growers in Wang To village and other villages around this site continued to decline.

\subsection{Contract farming system in hybrid tomato seed production}

Hybrid tomato seed production under contract farming in this site was initially established and developed by the private sector with little involvement from Thai government agencies. The contract seed production system is classified as employing the centralized model by Eaton and Shepherd (2001). This model describes a two way relationships between the growers and the seed companies. It does not involve intermediaries such as brokers, area seed agents, farmer organizations, NGOs and state agencies (Fig. 1 details the overall systems arrangement).

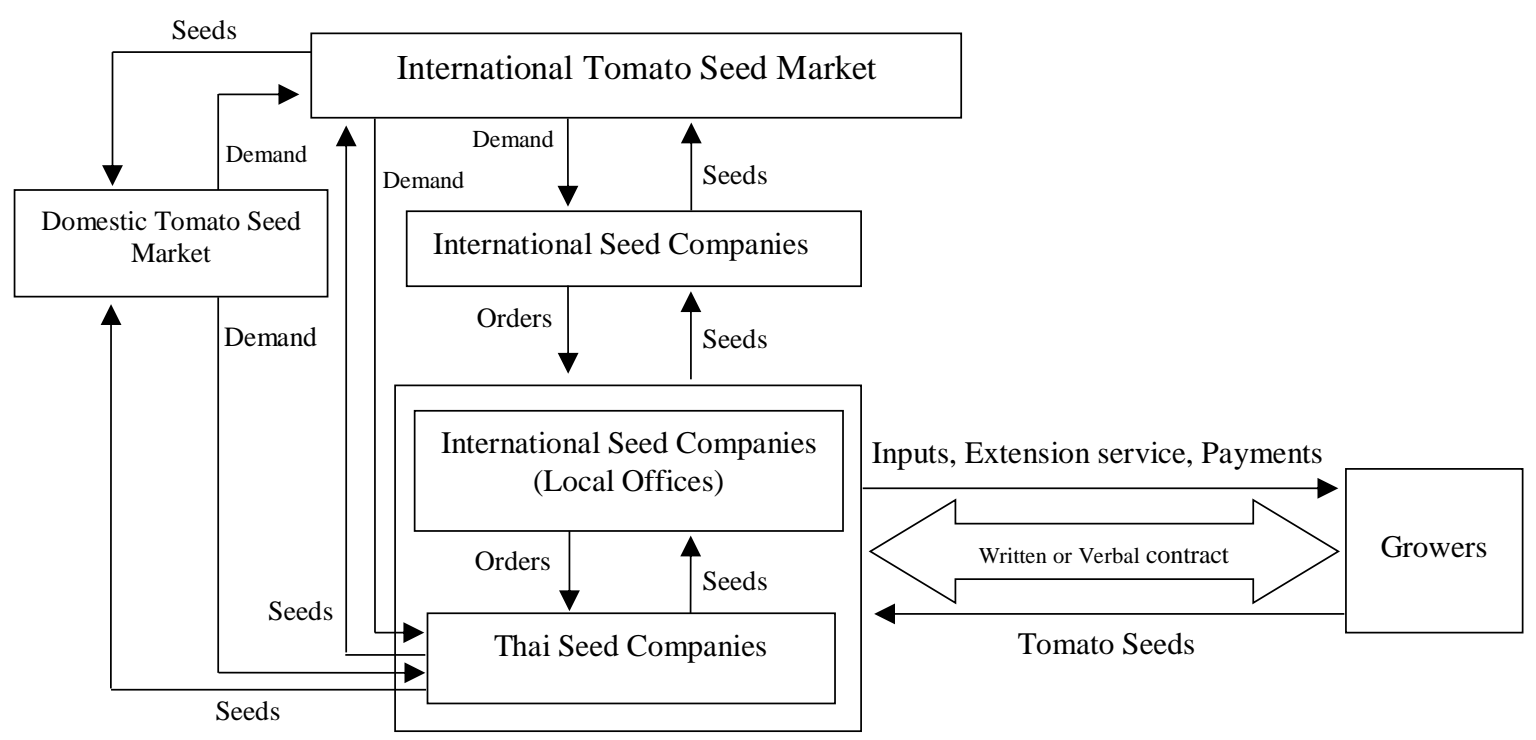

Figure 1. Contract farming system in hybrid tomato seed production in Northeast Thailand

The contracting process is based on a written or verbal contract between the seed company and individual growers. Under the contract, seed companies specify standards for the production and quality of hybrid tomato seeds to be delivered at a fixed time and price. They supply a complete package of support as inputs on credit and direct loans for hiring labor for a given quota of seed 
production. They provide extension services for crop cultivation, harvesting, and processing to the growers through regular field visits by field production technicians. Cost of all inputs and loans are deducted from the seed payment. But in fact, if the crop fails through no fault of the growers, these costs are usually forgiven by the companies. Some companies even give a small payment to the growers in order to encourage them to continue the production in the next growing season.

Nowadays most Thai seed companies still continue to have production arrangements with international seed companies of which they depend on for quality control and proprietary germplasm. Therefore, Thai seed companies must make their written or verbal contracts with individual growers and ensure that they match the conditions of their written contracts with several international seed companies. They do this in order to be responsive to orders and demand from the international seed market. In contrast, some Thai seed companies that have their own proprietary germplasm have produced seeds according to demand characteristics of domestic and international seed markets (as described in Fig. 1).

\subsection{Characterization of the study site}

The study site is situated $20 \mathrm{~km}$ northwest of Khon Kaen city. The annual average rainfall, minimum temperature, maximum temperature and relative humidity are $1,246.8 \mathrm{~mm}, 22.3^{\circ} \mathrm{C}$, $32.8^{\circ} \mathrm{C}$ and $72.0 \%$, respectively (Meteorological Department, 2014). The cool dry season takes place from November to February (Limpinuntana, 2001). Topography is undulating in the north and nonflood plains land in the south and southeast. The average altitude is $190-220$ meter above sea level. Key informants indicated that the undulating land which includes upland areas is mostly sandy loam, while the lowland is loamy sand soil. In the non-flood plains the soils are loamy sand and sandy clay.

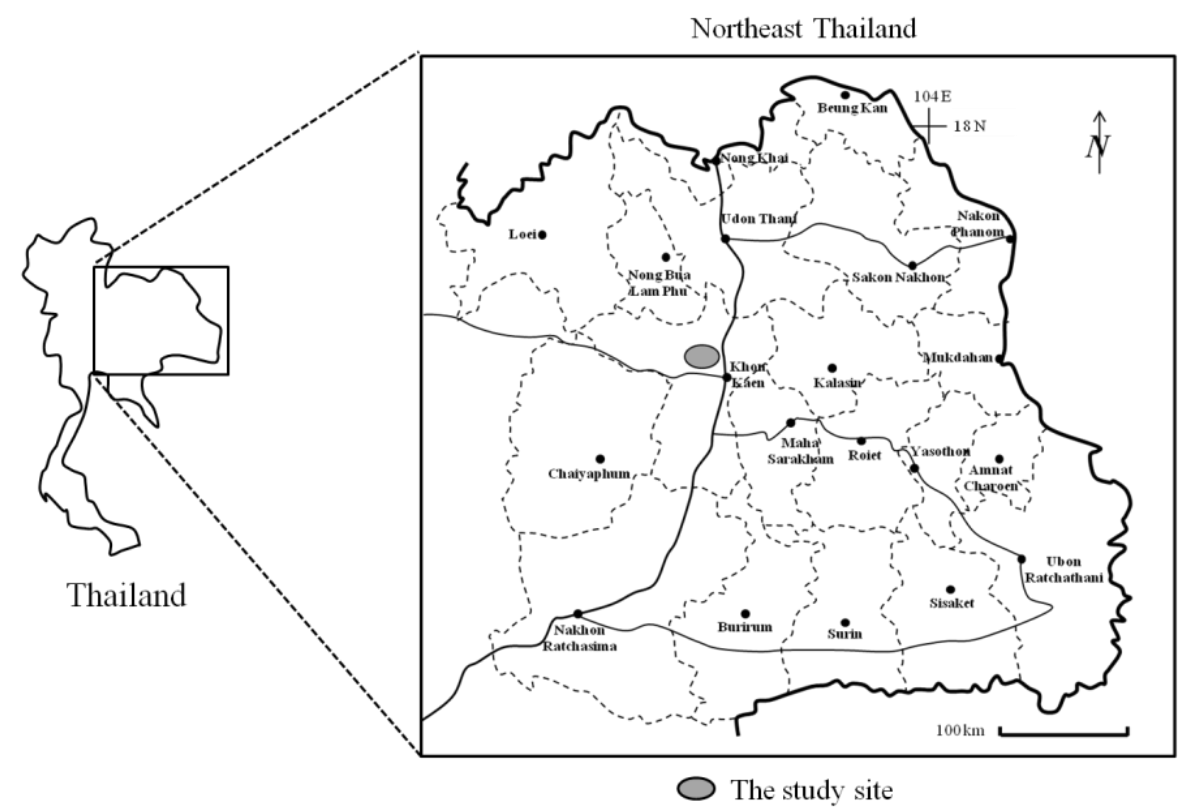

Figure 2. Map of the study site

The total land area of Lat $\mathrm{Na}$ Phiang and Wang To village is 1,416.6 and 1,436.8 hectares, respectively. There are 2 streams passing through the north of the village settlement, which traverses the non-flood plains in Lat Na Phiang. At Wang To, there is only one stream that passes through the north of village. Unfortunately for local farm production perspectives, all streams in this production site cannot supply water all year round.

There are 1,826 people and 368 households in Lat Na Phiang village and 2,822 people and 513 households in Wang To village. In Lat Na Phiang village $48.6 \%$ of all households are only engaged on 
agriculture as farmers and/or as agricultural laborers, $40.2 \%$ of households do both agriculture and non-agriculture as farmers and non-farm laborers, and $10.6 \%$ of households are solely involved in non-agriculture livelihoods. In Wang To village $60.2 \%$ of all households do both agriculture and nonagriculture, $19.7 \%$ of households do only agriculture, and $18.3 \%$ of households are exclusively involved in non-agriculture.

Table 1. Profile of the long term and the former growers in hybrid tomato seed production in the study area, in 2014/15

\begin{tabular}{|c|c|c|}
\hline Profile & $\begin{array}{l}\text { Long term growers } \\
(n=39)\end{array}$ & $\begin{array}{c}\begin{array}{c}\text { Former growers } \\
(n=11)\end{array} \\
\end{array}$ \\
\hline 1. Average age of the household head (year) & $49.5 \pm 5.7$ & $55.1 \pm 11.5$ \\
\hline \multicolumn{3}{|l|}{ 2. Education of household head (growers) } \\
\hline 2.1 Primary school & $33(84.6 \%)$ & $10(90.9 \%)$ \\
\hline 2.2 Secondary school & $6(15.4 \%)$ & $1(9.1 \%)$ \\
\hline $\begin{array}{l}\text { 3. Average land holding per household (ha) } \\
\text { 4. Average number of household members }\end{array}$ & $4.8 \pm 2.7$ & $3.9 \pm 2.1$ \\
\hline $\begin{array}{l}\text { 5. Average number of agricultural laborers } \\
\text { per household (people) }\end{array}$ & $2.3 \pm 0.9$ & $2.1 \pm 0.7$ \\
\hline \multicolumn{3}{|l|}{ 6. Household occupation (household) } \\
\hline $\begin{array}{l}6.1 \text { Only agriculture } \\
6.2 \text { Both agriculture and non-agriculture } \\
\text { sectors }\end{array}$ & $\begin{array}{l}10(25.6 \%) \\
29(74.4) \%\end{array}$ & $\begin{array}{l}2(18.2 \%) \\
9(81.8 \%)\end{array}$ \\
\hline \multicolumn{3}{|l|}{ 7. Crops cultivated (grower) } \\
\hline 7.1 Wet-season rice & $39(100.0 \%)$ & $10(90.9 \%)$ \\
\hline 7.2 Sugarcane & $32(82.1 \%)$ & $9(81.8 \%)$ \\
\hline 7.3 Cassava & $20(51.3 \%)$ & $4(36.4 \%)$ \\
\hline 7.4 Tomato for seeds & $39(100.0 \%)$ & 0 \\
\hline 7.5 Water melon for seeds & $8(20.5 \%)$ & $2(18.2 \%)$ \\
\hline 7.6 Luffa gourd for seeds & $5(12.8 \%)$ & 0 \\
\hline 7.7 Bitter gourd for seeds & $8(20.5 \%)$ & $3(27.3 \%)$ \\
\hline 7.8 Chili for seeds & $2(5.1 \%)$ & 0 \\
\hline 7.9 Long bean for fresh sale & $10(25.6 \%)$ & $3(27.3 \%)$ \\
\hline 7.10 Cucumber for fresh sale & $10(25.6 \%)$ & $2(18.2 \%)$ \\
\hline 7.11 Chili for fresh sale & 0 & $3(27.3 \%)$ \\
\hline 7.12 Sticky corn for fresh sale & 0 & 1 (9.1\%) \\
\hline $\begin{array}{l}\text { 7.13 Rubber } \\
\text { 8. Average number of crops in the system } \\
\text { (crop) } \\
\text { 9. Water resources for crops irrigation } \\
\text { (growers) }\end{array}$ & $\begin{array}{c}0 \\
4.5 \pm 1.3\end{array}$ & $\begin{array}{l}1(9.1 \%) \\
3.5 \pm 1.2\end{array}$ \\
\hline 9.1 Only private pond & $20(51.3 \%)$ & $7(63.4 \%)$ \\
\hline 9.2 Private pond and stream & $4(10.3 \%)$ & 0 \\
\hline $\begin{array}{l}\text { 9.3 Private pond and private ground water } \\
\text { 9.4 Private pond, private ground water and } \\
\text { stream }\end{array}$ & $\begin{array}{l}8(20.5 \%) \\
1(2.6 \%)\end{array}$ & $\begin{array}{c}3(27.3 \%) \\
0\end{array}$ \\
\hline $\begin{array}{l}\text { 9.5 Private pond and public ground water } \\
\text { 9.6 Private pond, private ground water and } \\
\text { public ground water }\end{array}$ & $\begin{array}{l}2(5.1 \%) \\
4(10.3 \%)\end{array}$ & 1 (9.1\%) \\
\hline
\end{tabular}

Source: In-depth interview.

The farming system of this site is rice based cultivation. The major crop is wet season rice in the 
lower part of the undulating and non-flood plains land, especially glutinous rice for home consumption and sale. After the rainy season, rice is harvested, vegetable for seeds and fresh sale are planted, including tomato, bitter gourd, luffa gourd, chili, long bean, cucumber, and sticky corn. The upland area is occupied by field crops, including sugarcane, cassava, and rubber, as well as seed crops of watermelon, bitter gourd, and luffa gourd during the rainy season.

\subsection{Profile of the long term growers and former growers in the study site}

Data of the 39 long-term growers and 11 former growers are presented in Table 1.

\subsection{Tomato seed production system}

Three cultivation patterns are required by the seed companies: 1) planting in double rows in beds in the open-air plot, 2) planting in double rows in the netted house, and 3) and single row planting in beds in the netted house. These three systems generate different income, which is one of the important factors influencing long term tomato seed production (Table 2).

Table 2. Characteristics of plots using different cultivation patterns in the study area, in 2014/15

\begin{tabular}{|c|c|c|c|}
\hline \multirow[b]{2}{*}{ Item } & \multicolumn{3}{|c|}{ Cultivation patterns } \\
\hline & $\begin{array}{c}\text { Double rows } \\
\text { in an open- air plots }\end{array}$ & $\begin{array}{c}\text { Double rows } \\
\text { in a netted houses }\end{array}$ & $\begin{array}{c}\text { Single row } \\
\text { in a netted houses }\end{array}$ \\
\hline Number of plots & 61 & 7 & 10 \\
\hline $\begin{array}{l}\text { Number of companies operating in the } \\
\text { area }\end{array}$ & 11 & 3 & 1 \\
\hline Mean area of the plots (ha/plot) ${ }^{1 /}$ & $0.06 \pm 0.02$ & $0.07 \pm 0.01$ & 0.16 \\
\hline $\begin{array}{l}\text { Mean number of female tomato plants } \\
\text { (plants/plot) }{ }^{1 /}\end{array}$ & $1,597.0 \pm 523.0$ & $1,833.0 \pm 288.0$ & $2,204.0 \pm 13.0$ \\
\hline Mean value of input credits ${ }^{1 /}$ (US\$2//plot) & $210.0 \pm 148.0$ & $493.0 \pm 280.0$ & $424.0 \pm 137.0$ \\
\hline Mean value of direct loans ${ }^{1 /}$ (US\$2//plot) & $261.0 \pm 123.0$ & $282.0 \pm 129.0$ & $409.0 \pm 53.0$ \\
\hline Mean seed yields (kg/plot) ${ }^{1 /}$ & $8.6 \pm 5.2$ & $10.3 \pm 5.0$ & $21.7 \pm 4.2$ \\
\hline Mean seed prices11/ (US\$2//kg) & $223.4 \pm 65.0$ & $263.2 \pm 80.0$ & $253.6 \pm 46.4$ \\
\hline $\begin{array}{l}\text { Mean gross income }{ }^{1 /} \\
\text { (US\$2//plot) }\end{array}$ & $1,792.6 \pm 1,046.0$ & $2,507.1 \pm 966.1$ & $5,412.4 \pm 1,018.6$ \\
\hline
\end{tabular}

Source: Primary survey

Note: $\quad 1 /$ Mean \pm standard deviation

2/ At 2015 exchange rate of 34.3 baht to one U.S. dollar

Most long-term growers (78.2\%) plant double rows in beds in the open-air plots and $64.1 \%$ of all growers produce 2 varieties of hybrid tomato seeds by contracting with 1-2 seed companies in a single production season. The average area for a tomato plot is 0.16 hectare with an average gross income of US\$ 4,814.2 $\pm 3,126.8$.

\subsection{Factors influencing long term tomato seed production}

Several different favorable and unfavorable factors influencing continuation of hybrid tomato seed production were identified, ranging from individual in-depth interviews with 39 long term growers, 11 former growers and 8 company staff. These factors included grower personal characteristics, company involvement, suitability of local environment, advanced technology, hybrid tomato seed production conditions, labor supply, and distance from urban areas (Table 3). 
Table 3. Factors influencing long hybrid term tomato seed production in the study area, by individual in-depth interviews

\begin{tabular}{|c|c|c|c|c|c|c|}
\hline \multirow[t]{2}{*}{ Factor } & \multicolumn{2}{|c|}{$\begin{array}{l}\text { Long term growers } \\
\qquad(n=39)\end{array}$} & \multicolumn{2}{|c|}{$\begin{array}{l}\text { Former growers } \\
\qquad(n=11)\end{array}$} & \multicolumn{2}{|c|}{$\begin{array}{l}\text { Company staff } \\
(\mathrm{n}=8)\end{array}$} \\
\hline & Favorable & Unfavorable & Favorable & Unfavorable & Favorable & Unfavorable \\
\hline $\begin{array}{l}\text { 1. Grower's personal } \\
\text { characteristics }\end{array}$ & $\begin{array}{c}22 \\
(56.4 \%)\end{array}$ & $\begin{array}{c}27 \\
(69.2 \%)\end{array}$ & $\begin{array}{c}10 \\
(90.9 \%)\end{array}$ & $\begin{array}{c}9 \\
(81.8 \%)\end{array}$ & $\begin{array}{c}8 \\
(100.0 \%)\end{array}$ & $\begin{array}{c}7 \\
(87.5 \%)\end{array}$ \\
\hline 2. Company involvement & & & & & & \\
\hline 2.1Company support & $\begin{array}{c}9 \\
(23.1 \%)\end{array}$ & $0^{*}$ & $0^{*}$ & $0^{*}$ & $\begin{array}{c}3 \\
(37.5 \%)\end{array}$ & $0^{*}$ \\
\hline $\begin{array}{l}2.2 \text { Relationship between the } \\
\text { company and the grower }\end{array}$ & $\begin{array}{c}3 \\
(7.7 \%)\end{array}$ & $\begin{array}{c}2 \\
(5.1 \%)\end{array}$ & $0^{*}$ & $\begin{array}{c}3 \\
(27.3 \%)\end{array}$ & $\begin{array}{c}4 \\
(50.0 \%)\end{array}$ & $\begin{array}{c}2 \\
(25.0 \%)\end{array}$ \\
\hline 3. Suitable environment & $\begin{array}{c}13 \\
(33.3 \%)\end{array}$ & $\begin{array}{c}4 \\
(10.3 \%)\end{array}$ & $0^{*}$ & $\begin{array}{c}3 \\
(27.3 \%)\end{array}$ & $\begin{array}{c}4 \\
(50.0 \%)\end{array}$ & 0* \\
\hline 4. Advanced technology & $\begin{array}{c}11 \\
(28.2 \%)\end{array}$ & $0^{*}$ & $0^{*}$ & $0 *$ & $\begin{array}{c}5 \\
(62.5 \%)\end{array}$ & $0^{*}$ \\
\hline $\begin{array}{l}\text { 5. Tomato seeds production } \\
\text { Conditions }\end{array}$ & $\begin{array}{c}4 \\
(10.3 \%)\end{array}$ & $0^{*}$ & $0^{*}$ & $\begin{array}{c}5 \\
(45.5 \%)\end{array}$ & $\begin{array}{c}1 \\
(12.5 \%)\end{array}$ & $0^{*}$ \\
\hline 6. Labor supply & $\begin{array}{c}2 \\
(5.1 \%)\end{array}$ & $\begin{array}{c}4 \\
(10.3 \%)\end{array}$ & $\begin{array}{c}2 \\
(18.2 \%)\end{array}$ & $\begin{array}{c}2 \\
(18.2 \%)\end{array}$ & $\begin{array}{c}2 \\
(25.0 \%)\end{array}$ & $\begin{array}{c}2 \\
(25.0 \%)\end{array}$ \\
\hline 7. Distance from urban area & $\begin{array}{c}1 \\
(2.6 \%)\end{array}$ & $0^{*}$ & $0^{*}$ & $0 *$ & $\begin{array}{c}2 \\
(25.0 \%)\end{array}$ & 0* \\
\hline
\end{tabular}

Source: Primary survey

Note: ${ }^{*}$ Not indicated by respondents

\subsubsection{Grower's personal characteristics}

Personal characteristics of the growers were identified as the most important factor influencing continuation of production by long term growers $(56.4 \%)$, affecting growers who have ceased production (90.9\%) and company staff (Table 3). These characteristics are diligence, patience, dedication, discipline and conforming to the company designed tasks, responsibility, honesty, and having excellent production and management skills, as well as a willingness to learn new technologies. These characteristics are similar to those reported by Benziger (1996), Rosset et al. (1999) and Tay (2002). All company staff confirmed that the growers in this site are excellent in production and management skills due to their long experience of over 30 years being engaged in their working relationship. They are highly knowledgeable and skilled in management of the whole process of production including land use, plot planning, staggered planting, management of both household and hired labor and capital management. They are also skilled in plot preparation, seedling raising, pollination, crop care and seed harvesting which all require elaborate, accurate, efficient and timely skills.

On the other hand, the long term growers $(69.2 \%)$, the former growers $(81.8 \%)$, and the company staff $(87.5 \%)$ identified personal characteristics among growers that are unfavorable factors influencing continuation of production (Table 3). These characteristics are passivity, impatience, lack of manual dexterity, unwillingness to do intensive jobs, lack of discipline and failing to conform to the company guidelines, lack of responsibility, and dishonesty. The former growers were also concerned about effects on their health of heavy use of insecticides and fungicides, including complains of eyesight and aging problems. Some of them also explained that they preferred to work as wage laborers in farm and non-farm jobs in order to earn regular income to pay for their living expenditures and children's education. The company staff indicated that the low seed yield and the substandard seed quality are due to growers lack of skills, but noted that the former growers would not admit their lack of skills. The importance of skills for the tomato seed growers under contract farming system should be further studied. 


\subsubsection{Company involvement}

\section{- Company support}

Long term growers (23.1\%) and company staff (37.5\%) indicated that company support is a favorable factor influencing continuation of production (Table 3 ). The growers are satisfied with the purchasing arrangements regulating seed price and volume as stated in the contract. Supporting packages consist of inputs credit, direct loans for hired labor, farm equipment, etc. Therefore, they do not need their own investment capital. Importantly, repayment of these credits and loans is waived by the companies if their crop fails when it was not the growers' fault, thus reducing risk among growers. This factor was also reported by Benziger (1996) and Martwanna and Lertrat (2007). Both credit and loans are deducted from the seed payment at the end of production season. Company staff indicated that the site allocation for specific tomato variety, technical advice and field monitoring by the company staff are important favorable factors influencing continuation of production. Furthermore, all of the companies also allow the growers to make multiple contracts with different companies in a single production season and they are not bound to continue with a particular contract in the next production season.

\section{- Relationship between the company and the growers}

Long term growers (7.7\%) and company staff (50.0\%) believed that a good relationship between the company and the growers is a favorable factor influencing continuation of production but no former growers mentioned this factor (Table 3 ). The long term growers explained that all companies served the growers according to the contracts with some flexibility. They forgave credit in certain occasions and provided loans for hired labor when crops failed. Some companies provide cash credit for grower household consumption or children's education, or supported paddy harvesting and assistance for village social activities, which was also reported in a separate study conducted by Martwanna and Lertrat (2007). Furthermore, company staff suggested that good personal relationships between company staff and growers are also important.

On the contrary, the long term growers $(5.1 \%)$, the former growers $(27.3 \%)$ and the company staff $(25.0 \%)$ pointed out that some aspects of the relationship between the companies and the growers are an unfavorable factor influencing continuation of production (Table 3). Some long term growers felt that they did not have bargaining power to negotiate for a better price. Moreover, some companies reduced the guaranteed price when the volume of hybrid tomato seeds exceeded the production quota as stated in the contract, as was also reported by Rosset et al. (1999). The former growers were not satisfied with the judgment of company staff of seed quality which led to refusal by the company to pay them. Furthermore, they were discontent with the process of seed testing and delayed payments, as was also similarly reported in a study from India (Sudha et al., 2006) and other sites in Thailand (Martwanna and Lertrat, 2007). Company staff also explained that some former growers had abandoned production because they could not afford the netted houses which are required by the company.

\subsubsection{Suitability of the local environment}

Long term growers (33.3\%) and company staff (50.0\%) believe that a suitable environment is a favorable factor in influencing the continuation of production (Table 3). Growers that can grow tomato plants in both the lower part of the undulating and non-flood plains land after harvesting the wet season rice crop held an advantage for continued production. The undulating topography of this site allows them to rotate and disperse their production plots to avoid or reduce wilt disease and root-knot nematode problems. Due to the short durations of hybrid tomato seed production, it also fits strategically into the wet season rice production systems, which was also reported by Tay (2002). 
On the contrary, long term growers (10.3\%) and former growers $(27.3 \%)$ pointed out that some former growers had suffered from wilt diseased, root-knot nematodes, and blossom end rot problems because of the soil in their plots (Table 3). In addition, drought was another unfavorable factor causing them to stop production.

\subsubsection{Advanced technology}

Some long term growers (28.2\%) and company staff (62.5\%) indicated that the availability of advanced technology is a favorable factor influencing continuation of production (Table 3 ). Mechanization with two wheeled hand tractors, four wheeled tractors, electric or diesel or gas water pumps, drip irrigation systems, agro-chemical sprayers and wet seed extractors have been successfully adopted to save time and labor. High disease and pest tolerance of tomato varieties, grafted seedling technology, netted houses and chemical pesticides have also been extended to the growers by the seed companies in order to increase yield. Growing techniques such as peat moss for the seedlings, seedling plastic trays, plastic sheets to cover beds and shade cloth have also been promoted by the companies, which have led to easier plot management and maintenance by the growers.

\subsubsection{Hybrid tomato seed production conditions}

Some long term growers $(10.3 \%)$ and company staff $(12.5 \%)$ indicated that the production conditions are a favorable factor influencing continuation of the production (Table 3 ). Tomato seed production requires shorter cultivation time ( 4 months) than the traditional crops such as cassava (8 - 12 months) and sugarcane (18 months). Thus small land holders and landless farmers can produce hybrid tomato seed because it only requires a small area of land for a short period. It requires highly intensive labor but only for a short period of time. Meanwhile, production yields a very high value product. These factors were also reported by Rosset et al. (1999) who concluded that hybrid tomato seed production is characterized by a strong economy of scale due to the intricate labor involved in the process. They also discovered that landless villagers were directly involved in producing hybrid tomato seeds.

On the contrary, former growers $(45.5 \%)$ said that the tomato seed production process was complex and required specific conditions and delicate management (Table 3). These included labor intensive and tedious operations requiring high manual dexterity, high input costs, high risk from disease and insect damage leading to heavy use of chemical pesticides and fungicides that adversely affected growers health.

\subsubsection{The local labor supply}

The long term growers $(5.1 \%)$, former growers (18.2\%) and company staff $(25.0 \%)$ indicated that labor supply is a favorable factor influencing continuation of production (Table 3). Plot planning and plot size, $200-1600 \mathrm{~m} 2$, allow them to use available household labor and shared labor (relatives) within their own village to save labor costs. Although this production site is close to city, where off-farm work is easily available, the growers preferred to stay on their farms with their families to produce hybrid tomato seeds, which can generate higher incomes rather than being employed as daily wage workers.

On the contrary, long term growers (10.3\%), former growers $(18.2 \%)$ and company staff $(25.0 \%)$ indicated that labor supply was an unfavorable factor influencing continuation of production (Table 3). They pointed out that because the site is close to the city many of the villagers are employed in the non-agricultural sector and some of them depart seasonally as overseas migrants, which results in a shortage of labor for hybrid tomato seed production. Moreover, the demand for labor by industrial development and service sectors in the vicinity has led to wage increases for workers in 
hybrid tomato production. This finding is confirmed by Saenjan (1998), Rosset et al. (1999), and Martwanna and Lertrat (2007).

\subsubsection{Distance from urban areas}

Some of the long term growers $(2.6 \%)$ and company staff $(25.0 \%)$ said that the distance between village and urban areas was a factor influencing continuation of production (Table 3 ). The short distance $(20 \mathrm{~km})$ between Lat Na Phiang village and Khon Kaen city where the company offices are located lowers transaction costs, allowing company staff to regularly get in touch with growers, thus increasing conditions of trust and encouragement.

In group interviews, long term growers and former growers were asked to rank and order the favorable and unfavorable factors influencing long term tomato seed production in rainfed areas (see Table 4 for a detailed breakdown of these perceptions).

Table 4. Ranking of favorable and unfavorable factors influencing long term hybrid tomato seed production in the study area, by group interview

\begin{tabular}{lcccc}
\hline \multicolumn{1}{c}{ Factor } & \multicolumn{2}{c}{ Long term grower's group } & \multicolumn{2}{c}{ Former grower's group } \\
\cline { 2 - 5 } & Favorable & Unfavorable & Favorable & Unfavorable \\
\hline Grower's characteristics & 1 & 1 & 1 & 2 \\
Company involvement & 2 & $0^{*}$ & $0^{*}$ & 3 \\
Advanced technology & 3 & $0^{*}$ & $0^{*}$ & $0^{*}$ \\
Suitable environment & 4 & $0^{*}$ & $0^{*}$ & 1 \\
Labor supply & 5 & 2 & 2 & $0^{*}$ \\
\hline
\end{tabular}

*Not indicated by respondents

The majority of the long term growers believe that the companies rely on them. They state that this is demonstrated by the willingness of companies to forgive credits and loans for hired labor when crops failed. Moreover, some companies also provide cash credit for growers' household consumption, children's education, and also supported hiring of laborers for paddy harvesting. The company also supported village social activities, as was also reported by Martwanna and Lertrat (2007). Therefore, we can conclude that knowledgeable and skillful growers are a vital factor for sustaining long term hybrid tomato seed production.

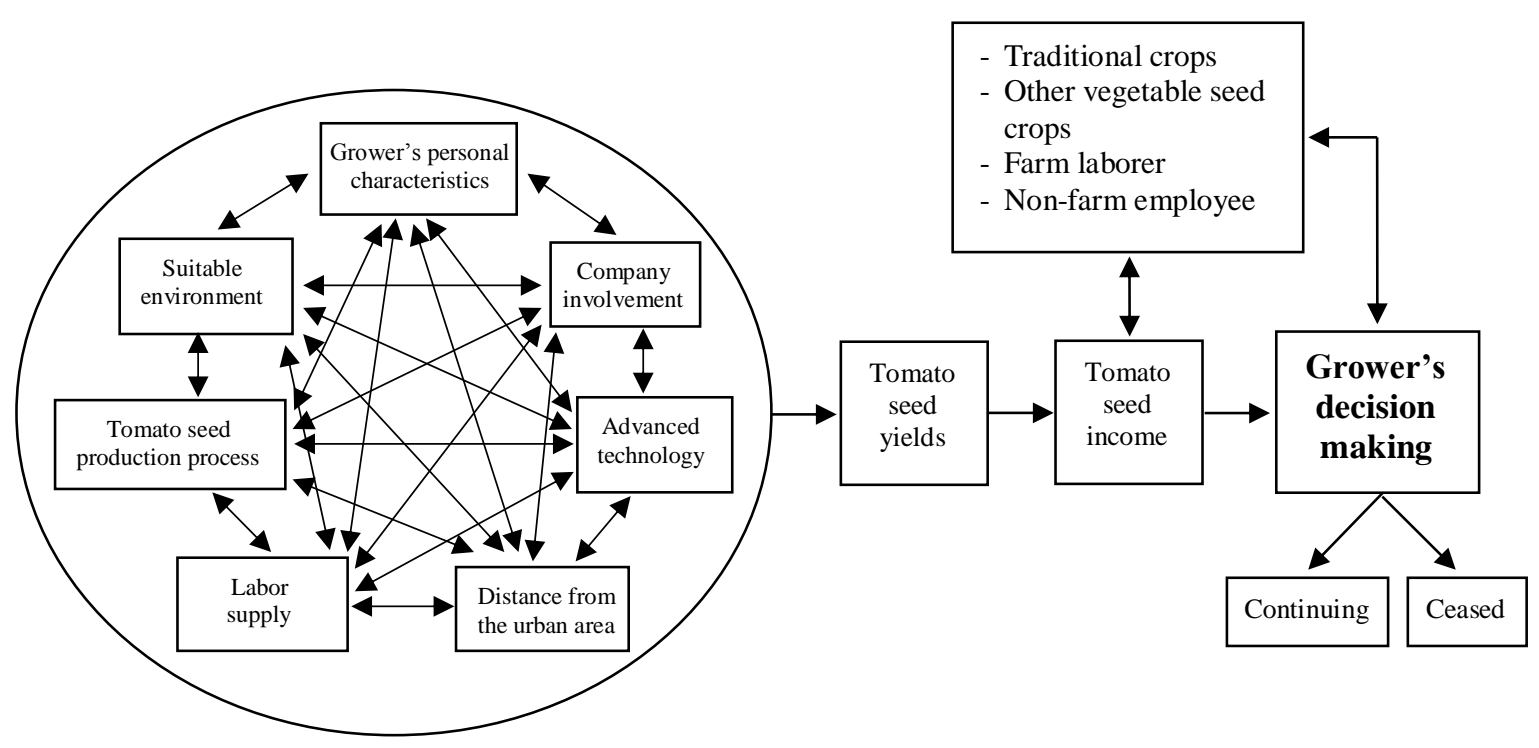

Figure 3. Grower's decision making for continuing or ceasing hybrid tomato seed production 


\subsection{Grower decision making on continuation of hybrid tomato seed production}

There are several factors influencing grower decision making about continuing or ceasing hybrid tomato seed production (Fig. 3). Several different factors interact to determine the amount of income that growers gain from seed production. Earning a high income from producing hybrid tomato seeds is a powerful factor for the growers to begin and continue hybrid tomato seed production, which has also been reported in other contexts by Benziger (1996), Sudha et al. (2006), and Sarkar et al. (2011) at the Lam Nam Oon Irrigation Project in Northeast Thailand, in Karnataka of India, and in Rangpur district of Bangladesh, respectively. Fig. 3 summarizes grower decision making for continuing or ceasing hybrid tomato seed production.

\section{Conclusion}

Many researchers, NGOs, and the media have a negative perception of the impact of contract farming on growers. However, this study has provided a more complete picture, identifying certain positive effects, notably the high income earned by some growers. We have also found that the relationship between the companies and the growers is largely a positive one. This may reflect the fact that the companies are heavily dependent on maintaining a pool of highly skilled and knowledgeable growers who can reliably produce high quality seed. In order to maintain this positive relationship, the companies have to offer favorable contractual terms to the growers, including providing them with credit and supporting social activities in their villages. Because of these positive aspects, some farmers have operated under the contract farming for a long time.

It is especially noteworthy that this type of contract farming involves a two way relationship between the growers and the seed companies and does not involve any intermediaries or state intervention. The relationship is a two way one because the companies need to work with skilled and knowledgeable farmers if they are to obtain high quality seed that meets the standards of the international market. For their part, the growers need the support of the companies because they cannot produce hybrid tomato seeds without contracts. The proprietary nature of the germplasm and the need for quality control and marketing services also determines the reflexive nature of this relationship. Furthermore, this relationship structures the ability of the growers to meet the companies demand through their knowledge, management and technical skills. Grower personal characteristics were also determined as an important factor in this study, in which management and technical skills were identified by both the company staff and growers as an important factor for long term production. Further study to understand how the growers constructed their bargaining power with the companies through their knowledge and skills is recommended.

\section{Acknowledgements}

This paper is based on the first author's dissertation research in the Program on System Approaches in Agriculture, Faculty of Agriculture, Khon Kaen University. The research was supported by a grant (BRG5680008) from the Thailand Research Fund (TRF) Basic Research Program to Prof. Terry Rambo, but the views expressed in this paper are not necessarily shared by TRF.

\section{References}

Benziger, V. (1996). Small Fields, Big Money: Two Successful Programs in Helping Small Farmers Make the Transition to High Value-Added Crops. World Development 24(11): 1681-1693.

Da Silva, C.A.B. (2005). The Growing Role of Contract Farming in Agri-food Systems Development: Drivers, Theory and Practice. Rome: FAO.

Delforge, I. (2007). Contract Farming in Thailand: A view from the farm. Focus on the Global South CUSRI. Bangkok, Thailand: Chulalongkorn University Social Research Institute. 
Eaton, C. and A.W. Shepherd. (2001). Contract Farming: Partnerships for growth. FAO Agricultural Services Bulletin 145. Rome: FAO.

Gedgaew, C., S. Simaraks, and A.T. Rambo. (2017). Trends in Hybrid Tomato Seed Production under Contract Farming in Northeast Thailand. Southeast Asian Studies 6(2): 339-355.

Kerdsuk, W., S. Chartbunchachai, S. Usanawarong, J. Reungchayachatuporn, C. Yenchai, S. Boonsanure, P. Saenchaisuriya, and P. Ketsomboon. (1996). Self-Care Behavior of the Northeast Farmers Involved in The Dry Season Seed Production: Case Study in 2 villages. Research report. Khon Kaen, Thailand: Research Development Institute, Khon Kaen University.

Limpinuntana, V. (2001). Physical factors related to agricultural potential and limitations in northeast Thailand. In Natural Resource Management Issues in the Korat Basin of Northeast Thailand: An Overview, ed. S.P. Kam, C.T. Hoanh, G. Trebuil, and B. Hardy, 3-17. International Rice Research Institute.

Martwanna, N., and K. Lertrat. (2007). Contract Farming: Seed Production of Seed Companies in Thailand. Thailand Research Fund report. Bangkok, Thailand: Thailand Research Fund.

Meteorological Department. 2014. Climatological data of Thailand for 30 year period (1981-2010). Meteorological data report No. 551-586-01-2556. Bangkok, Thailand: Meteorological Department.

Rosset, P., R. Rice, and M. Watts. (1999). Thailand and the World Tomato: Globalization, New Agricultural Countries (NACs) and the Agrarian Question. International Journal of Sociology of Agriculture and Food 8: 71-94.

Saenjan, V. (1998). Future Prospect of Small and Medium Size Agribusiness in Thailand. In Proceedings of the Second International Seminar on Agribusiness and Its Impact on Agricultural Production in Southeast Asia (DABIA II), ed. A. Patanothai, and P. KeeratiKasikorn, 159-180. Khon Kaen, Thailand: Faculty of Agriculture, Khon Kaen University.

Sarkar, M.A.R., M.H.A. Rashid, and M.R. Sarker. (2011). Contract Farming in Tomato Seed Production in Rangpur District of Bangladesh: A Financial Analysis. Progressive Agriculture 22(1\&2): 169179.

Siamwalla, A. (1996). Thai Agriculture: From Engine of Growth to Sunset Status. TDRI Quarterly Review 11(4): 3-10.

Singh, S. (2005). Contract Farming System in Thailand. Economic and Political Weekly December 31, 2005: 5578-5586.

Sriboonchitta, S., and A. Wiboonpoongse. (2008). Overview of Contract Farming in Thailand: Lessons learned. ADBI Discussion Paper 112. Tokyo: Asian Development Bank Institute.

Sudha, M., T.M. Gajanana, and D.S. Murthy. (2006). Economic Impact of Commercial Hybrid Seed Production in Vegetables on Farm Income, Employment and Farm Welfare - A Case of Tomato and Okra in Karnataka. Agricultural Economics Research Review 19(July-December 2006): 251-268.

Tay, D. (2002). Vegetable Hybrid Seed Production. In Proceedings International Seed Seminar: Trade Production and Technology. Oct - 2002. http://www.seedconsortium.org /PUC/ elibraryExtension.html. Accessed 20 March 2015.

Winters, P., P. Simmons, and I. Patrick. (2005). Evaluation of Hybrid Seed Contract between Smallholders and a Multinational Company in East Java, Indonesia. The Journal of Development Studies 41(1): 62-89. 